\title{
Preparation of serocolostrum by membrane microfiltration
}

\author{
Michel PIOT, Jacques FAUQUANT, Marie-Noëlle MADEC, \\ Jean-Louis MAUBOIS* \\ UMR Science et Technologie du Lait et de l'Oeuf, INRA-Agrocampus, 65 rue de St-Brieuc, \\ 35042 Rennes Cedex, France
}

Received 5 November 2003 - Accepted 20 January 2004

Published online 7 June 2004

\begin{abstract}
Treatment of bovine, equine and caprine colostrum by membrane microfiltration with a pore size of $0.1 \mu \mathrm{m}$ was studied in order to obtain a specific separation of whey colostrum components. These components are most interesting for imparting passive immunity and positive physiological action to newborn mammals. From the carrying out of $80 \mathrm{~kg}$ batches of colostrum, the microfiltration equipment used allowed the recovery of at least $80 \%$ of the $\mathrm{IgG}$ and other minor whey proteins in the microfiltrate. This liquid, named serocolostrum, is crystal clear, free of blood and somatic cells as well as fat globules and casein micelles, and it has a high hygienic and bacteriological quality (less than $10 \mathrm{CFU} \cdot \mathrm{mL}^{-1}$ ). Specific concentration of the serocolostrum IgG proteins by high molecular weight cut-off (MWCO: $100 \mathrm{~kg} \cdot \mathrm{mol}^{-1}$ ) membrane ultrafiltration was also studied in order to obtain purified IgG products suitable for preliminary animal trials. Purity (IgG/TS) as high as $90 \%$ was obtained. The use of a lower MWCO UF membrane $\left(8 \mathrm{~kg} \cdot \mathrm{mol}^{-1}\right)$ allowed concentrations of growth factors (TGF- $\beta$ and IGF-1) but the observed separation did not agree with the data of the literature, i.e. a binding of IGF-1 with a $45 \mathrm{~kg} \cdot \mathrm{mol}^{-1}$ protein.
\end{abstract}

Colostrum / membrane / microfiltration / ultrafiltration / serocolostrum / IgG / TGF- $\beta$ / IGF-1

Résumé - Préparation de « sérocolostrum » par microfiltration sur membrane. La mise en contact de colostrums de vache, jument et chèvre avec une membrane de microfiltration ayant un diamètre de pores de $0,1 \mu \mathrm{m}$ permet de réaliser une séparation spécifique des composants du sérum, composants d'intérêt pour obtenir une immunisation passive du jeune mammifère. Avec l'équipement MF pilote utilisé, la mise en œuvre de $80 \mathrm{~kg}$ de colostrum conduit à une récupération d'au moins $80 \%$ des IgG et des protéines mineures dans le microfiltrat. Ce liquide, appelé sérocolostrum, est limpide, il ne contient ni cellule sanguine, ni cellule somatique, ni globule gras, ni micelle de caséine. Sa qualité bactériologique est particulièrement élevée (moins de $10 \mathrm{CFU} \cdot \mathrm{mL}^{-1}$ ). La concentration spécifique des protéines IgG, contenues dans le sérocolostrum par ultrafiltration sur membrane (ayant un pouvoir de coupure élevé, $100 \mathrm{~kg} \cdot \mathrm{mol}^{-1}$ ) a également été étudiée avec pour objectif l'obtention de produits enrichis en $\operatorname{IgG}$ (pureté d'au moins $90 \%$ ) pouvant être utilisés en expérimentations sur les jeunes animaux. Grâce à l'emploi de membranes UF de plus petit pouvoir de coupure $\left(8 \mathrm{~kg} \cdot \mathrm{mol}^{-1}\right)$, la concentration spécifique des facteurs de croissance (TGF- $\beta$, IGF-1) a pu être étudiée. La perméation déterminée pour l' IGF-1 n'était pas en accord avec les données de la littérature qui précise que dans le colostrum et dans le lait, ce facteur de croissance serait lié avec une protéine de $45 \mathrm{~kg} \cdot \mathrm{mol}^{-1}$.

Colostrum / membrane / microfiltration / ultrafiltration / sérocolostrum / IgG / TGF- $\beta$ / IGF-1

\footnotetext{
* Corresponding author: maubois@rennes.inra.fr
} 


\section{INTRODUCTION}

Colostrum is defined as the mixture of the lacteal secretions produced by the mammary gland during the three days following parturition. Its composition greatly varies during these three days $[1,6]$. Total solids, protein, casein, fat and mineral salts, expressed in \%, respectively, decrease from $23.9 ; 14.0 ; 4.8 ; 6.7$ and 1.11 to $13.6 ; 4.1 ; 2.9$; 4.3 and 0.81 . Lactose increases from 2.7 to $4.7 \%$. It is known for its laxative property [13] due to a thermoresistant component causing fast removal of the "meconium" from the intestinal tracts of the offspring [10].

Because of its high content in immunoglobulins (Ig), mainly (95\%) of the subclass $\mathrm{IgG}_{1}$ specifically concentrated from blood by the mammary cells [21], colostrum was considered as having an essential physiological action for many species (cow, horse and pig). Indeed, it imparts passive immunity to the newborn mammals through a direct passage across the intestinal cells (for a limited period of time: 12 $48 \mathrm{~h}$ ), which is hypothesised to be either specific (horse and pig) or non-specific (cow and goat) [16]. Several studies which were reviewed by Scammell [35] also provide evidence of the efficacy of colostrum in human clinical applications such as treatment of acute infant gastroenteritis [11] and chronic refractory diarrhoea due to Cryptosporidium in AIDS patients [29,31]. More recently, a lot of attention has been paid to colostrum because of its exceptional content in (i) many growth factors such as EGF (Epithelial Growth Factor), IGF (Insulin Growth Factor), NGF (Nerve Growth Factor) and TGF- $\beta_{2}$ (Transforming Growth Factor), which play a critical role in the regulation and differentiation of a variety of cells $[15,16,26-28]$ and (ii) cytokines [10] with particular interest in a proline-rich polypeptide which was shown to improve the outcome of Alzheimer's Disease patients with mild to moderate dementia [18]. Consequently, colostrum and its derivatives may be of a great interest to the cosmeceutical and nutraceutical markets.
Production of colostrum by most healthy cows is in excess of the calf's requirements [6] and consequently, preservation of surplus colostrum for future use has been largely studied. Indeed, the bacteriological quality of colostrum is often very poor (Initial Total Count close to or even higher than $10^{6} \mathrm{CFU} \cdot \mathrm{mL}^{-1}$ with a high content in coliforms and some pathogens such as E. coli and Salmonella typhimerium) [6]. Colostrum can also contain some proportion of blood. Attempts to avoid the irreversible degradation of colostrum properties have been reviewed by Foley and Otterby [6]. Heat treatment cannot be envisaged because of the high thermal sensibility of Ig. Controlled acidification either with lactic starters or with mineral acid was proposed, but it leads to coagulation of the casein. Chemical food additives (sodium benzoate or benzoic acid) and even formaldehyde have been proposed, but their use at farm level is risky, and efficiency as well as acceptability by the calves were not satisfactory. Immediate freezing at $-20{ }^{\circ} \mathrm{C}$ is considered to be the best means to prevent nutrient breakdown during storage. However, microbial contaminants are still present in the frozen product and the thawing temperature and time may allow undesirable fermentation to occur. Bactofugation of skimmed colostrum was also proposed $[39,40]$ but it is well known that this technology reduces the bacterial count by only $95 \%$, which is largely insufficient. Ionisation of colostrum for feeding calves has been studied and it is officially authorised, at a maximal dose of $10 \mathrm{kGy}$ [14], but as it is well known, it is likely that ionisation induces undesirable flavour compounds from milkfat breakdown and it also leaves inside the treated colostrum dead microbial cells with most of their enzymatic activities. More recently, Mortensen [25] has proposed using the same process, i.e. membrane (pore size $1.4 \mu \mathrm{m}$ ) microfiltration of skimmed colostrum, as the one applied to removing contaminating bacteria from skim milk but no indication was given in this patent on the decimal reduction of the total count observed in the MF colostrum. 
In spite of the supposed immunoprotective effect of colostrum leukocytes [12,36] and a higher and different glycosylation of casein GMP (glycomacropeptide) which could lead to a closer similarity with human GMP [2], in a first approach, it can be concluded that most of the interesting components are in the whey part of the colostrum. Considering, on the other hand, the potential of membrane microfiltration for the selective separation of milk particles [5, 24, 32], application of this technology to colostrum as already patented by Garcin et Paviot [7] appears to be an elegant way to prepare, in mild conditions of time and temperature, a high quality "serocolostrum" without blood red cells, somatic cells, fat globules, bacteria and casein micelles of which all the whey proteins and mainly the $\operatorname{IgG}$ could easily be specifically concentrated by membrane ultrafiltration. This paper deals with the studies and the results obtained by our team with bovine, caprine and equine colostrums.

\section{MATERIALS AND METHODS}

\subsection{Colostrums}

Amounts of 18 to $80 \mathrm{~kg}$ of pooled frozen bovine, caprine or equine colostrum were thawed at a maximal temperature of 30 $40{ }^{\circ} \mathrm{C}$ in jacketed tanks and diluted by $50 \%$ by adding either $\mathrm{RO}$ water containing $\mathrm{KCl}$ $0.03 \mathrm{~mol} \cdot \mathrm{L}^{-1}$ and $0.02 \mathrm{~mol} \cdot \mathrm{L}^{-1} \mathrm{NaCl}$ or milk ultrafiltrate, and then separated on "Elecrem" equipment(Elecrem, Aubervilliers, France). The separated cream which represented 10 to $15 \%$ (v/v), was discarded or, in order to improve the yield in skimmed colostrum, diluted with the aforementioned saline solution and re-submitted to separation.

\subsection{Membrane microfiltrations}

The skimmed diluted colostrums were maintained at $33{ }^{\circ} \mathrm{C}-37{ }^{\circ} \mathrm{C}$ for $20 \mathrm{~min}$ in order to reach stabilisation of the milk saline equilibrium. Then, they were introduced and maintained at temperature lower than $40{ }^{\circ} \mathrm{C}$ in microfiltration equipment (Tetra Pak Processing SNC, Le Blanc Mesnil, France) comprising (i) according to the volume of colostrum to be treated, between 0.2 and $4.6 \mathrm{~m}^{2}$ of "Membralox" membrane (Pall Exekia, Bazet, France), with an average pore size of $0.1 \mu \mathrm{m}$ and (ii) a recirculation loop of the microfiltrate in order to obtain a Uniform Transmembrane Pressure (UTP) $[32,34]$. According to the experiments, continuous diafiltration (as the same rate as the MF flux) with 8 to 10 diavolumes of the aforementioned saline solution was realised on the diluted colostrums (dilution rates ranging from 0.50 to 0.88 ) in order to yield a maximum amount of $\mathrm{IgG}$ in the microfiltrate.

\subsection{Membrane ultrafiltrations}

Proteins contained in the microfiltrates were then concentrated (Volumic Concentration Factor or VCF ranging from 15 to 30) in ultrafiltration equipment comprising either $9.7 \mathrm{~m}^{2}$ of spiral wound polymeric membrane with a cut-off of $5 \mathrm{~kg} \cdot \mathrm{mol}^{-1}$ (T.I.A., Bollène, France), or $6.8 \mathrm{~m}^{2} \mathrm{M} 1$ or M5 ceramic membrane (Rhodia Orelis, St Maurice de Beynost, France) with, respectively, a cut-off of $100 \mathrm{~kg} \cdot \mathrm{mol}^{-1}$ and $10 \mathrm{~kg} \cdot \mathrm{mol}^{-1}$ and finally, a $6.65 \mathrm{~m}^{2}$ piece of equipment equipped with a "sunflower" Tami ceramic membrane (Nyons, France) with a cut-off of $8 \mathrm{~kg} \cdot \mathrm{mol}^{-1}$.

\subsection{Freeze-drying}

Serocolostrum fractions and UF retentates were freeze-dried in CIRP CS 10-0.8 equipment (SGD Serail, Argenteuil, France) and then kept at room temperature until the animal experiments, the carrying out of which, and the analytical measurements used, have already been described by Grongnet et al. [8] for the feeding of calves, Chavatte-Palmer et al. [3] and Clément et al. [4] for the feeding of newborn foals and by Le Huërou-Luron et al. [17] and Marion et al. [22] for the feeding of piglets. 
Table I. Microfiltrate composition $\left(\mathrm{g} \cdot \mathrm{kg}^{-1}\right)$.

\begin{tabular}{lccc}
\hline & TS & TNM & IgG \\
\hline Bovine & $9.6-23.7$ & $3.8-11.6$ & $2.2-5.0$ \\
Caprine & $5.5-10.1$ & $3.2-6.2$ & $2.1-5.3$ \\
Equine & $10.5-11.7$ & $3.8-4.1$ & $1.8-2.5$ \\
\hline
\end{tabular}

TS: Total Solids; TNM: Total Nitrogen Matter (N × 6.38); IgG: Immunoglobulin G.

\subsection{Analysis}

Total solids, fat, proteins and lactose were determined by using reference analytical methods previously described by Saboya et al. [33].

Immunoglobulins ( $\mathrm{IgG})$ were determined as described by Mancini [20] or by RP-HPLC on a Waters 600 E system (Waters S.A., St Quentin en Yvelines, France) equipped with a PLRP-S 1,000 A $150 \times$ $4.6 \mathrm{~mm}$ column (Touzart et Matignon, Vitry sur Seine, France). Elution was done by using HPLC-grade acetonitrile (ACN) (Carlo Erba, Nanterre, France) containing $0.1 \%$ trifluoroacetic acid (TFA) in gradient conditions as follows: 35 to $38 \%$ ACN for $8 \mathrm{~min}$ and increase $\mathrm{ACN}$ concentration to $43 \%$ in $10 \mathrm{~min}$. Detection was carried out at $280 \mathrm{~nm}$. Standards were bovine IgG (Sigma-Aldrich Chimie, St Quentin Fallavier, France) and equine IgG (gift from Prof. Grongnet).

TGF- $\beta$ contents were determined by sandwich enzyme immunoassay (Quantikine, R \& D systems, Abingdon, UK).

IGF-1 contents were determined according to Louveau et al. [19].

\section{RESULTS AND DISCUSSION}

\subsection{Microfiltration experiments}

Whatever the origin of the colostrum (bovine, equine or goat), permeation fluxes around $25 \mathrm{~L} \cdot \mathrm{m}^{-2} \cdot \mathrm{h}^{-1}$ were obtained with a UTP varying between 40 and $50 \mathrm{kPa}$. Such fluxes are at least 3 times less than those observed when "ideal whey" is separated from milk [25, 37, 38], probably because of the lower temperature used $\left(37^{\circ} \mathrm{C}\right.$ instead of $50{ }^{\circ} \mathrm{C}$ ) and the high content (ranging from 38.2 to $13.6 \mathrm{~g} \cdot \mathrm{kg}^{-1}$ ) in large-sized IgG protein molecules. The composition of the crystal clear (slightly yellow-pink coloured) microfiltrate ("serocolostrum") varied according to the protein content of the treated colostrum and the rate of dilution ( 0.50 to 0.88$)$. The range of variation of TS, TNM and IgG contents in this diluted serocolostrum fraction for the three studied species is summarised in Table I. As expected, the proportion of IgG in the TNM largely varies according to the original colostrum composition linked to the number of mixed post-partum milkings and the rate of dilution used before skimming and for diafiltration. Instantaneous MF rejection coefficients for IgG were determined with caprine 1st and 2nd milking colostrums. They increased similarly versus time as expected (impoverishment of their content in the MF retentate) from 0.46 to 0.89 and from 0.52 to 0.87 , respectively. No bacteria was enumerated in all of the obtained "serocolostrums", whatever the initial count (between $10^{6}$ and $10^{7} \mathrm{CFU} \cdot \mathrm{mL}^{-1}$ ), and samples were kept at room temperature for one year without any growth [7].

\subsection{Ultrafiltration experiments}

The parameters used in the ultrafiltration experiments are summarised in Table II. Average fluxes, as is very well-known, were varying according to the temperature used, the protein content of the treated "serocolostrum", the molecular cut-off of the UF membrane utilised and the VCF between 12 and $53 \mathrm{~L} \cdot \mathrm{m}^{-2} \cdot \mathrm{h}^{-1}$. Table III summarises the range of determined composition of the obtained ultrafiltrates and retentates. For bovine 
Table II. Operating conditions for ultrafiltration of colostrum microfiltrate (pooled with diafiltrate).

\begin{tabular}{lcccc}
\hline & Type of membrane & $\begin{array}{c}\text { Temperature } \\
\left({ }^{\circ} \mathrm{C}\right)\end{array}$ & $\begin{array}{c}\text { Transmembrane } \\
\text { pressure } 10^{-5} \mathrm{~Pa}\end{array}$ & $\begin{array}{c}\text { Flux } \\
\left(\mathrm{L} \cdot \mathrm{h}^{-1} \cdot \mathrm{m}^{-2}\right)\end{array}$ \\
\hline Bovine & $100000 \mathrm{~g} \cdot \mathrm{mol}^{-1}$ & $20-41$ & $0.8-2.8$ & $12-32$ \\
& $\begin{array}{c}0.02 \mu \mathrm{m} \\
8000 \mathrm{~g} \cdot \mathrm{mol}^{-1}\end{array}$ & $\begin{array}{c}19-27 \\
35-50\end{array}$ & $2.8-1.1$ & $18-53$ \\
& & & & $27-43$ \\
\hline Caprine & $5000 \mathrm{~g} \cdot \mathrm{mol}^{-1}$ & $21-22$ & $0.5-3.2$ & $18.6-19.6$ \\
1st milking & $5000 \mathrm{~g} \cdot \mathrm{mol}^{-1}$ & $21-26$ & $1.2-1.9$ & $17-31$ \\
2nd milking & $10000 \mathrm{~g} \cdot \mathrm{mol}^{-1}$ & $30-35$ & $3-3.5$ & 25 \\
\hline Equine & $5000 \mathrm{~g} \cdot \mathrm{mol}^{-1}$ & $21-31$ & $85-2.3$ & $13-33$ \\
\hline
\end{tabular}

Table III. Retentate and ultrafiltrate composition.

\begin{tabular}{|c|c|c|c|c|c|}
\hline & & $\begin{array}{l}\text { Type of membrane } \\
\quad\left(\mathrm{g} \cdot \mathrm{mol}^{-1}\right)\end{array}$ & $\begin{array}{c}\mathrm{TS} \\
\left(\mathrm{g} \cdot \mathrm{kg}^{-1}\right)\end{array}$ & $\begin{array}{c}\mathrm{TNM} \\
\left(\mathrm{g} \cdot \mathrm{kg}^{-1}\right)\end{array}$ & $\underset{\left(\mathrm{g} \cdot \mathrm{kg}^{-1}\right)}{\mathrm{IgG}}$ \\
\hline \multirow{3}{*}{ Bovine } & UF & \multirow{2}{*}{100000} & $8.4-8.6$ & $1.1-1.4$ & $0.4-0.6$ \\
\hline & Ret. & & 94-112 & 89-105 & $65-84$ \\
\hline & $\begin{array}{l}\text { UF } \\
\text { Ret. }\end{array}$ & 8000 & $\begin{array}{c}53.8 \\
121.9\end{array}$ & $\begin{array}{c}1.8 \\
60.9\end{array}$ & \\
\hline \multirow{2}{*}{ Caprine } & UF & 5000 & $\begin{array}{c}\text { n.d. } \\
"\end{array}$ & $\begin{array}{c}\text { n.d. } \\
"\end{array}$ & $\begin{array}{l}0.05^{1} \\
0.03^{2}\end{array}$ \\
\hline & Ret. & 5000 & $\begin{array}{c}109^{1} \\
48^{2}\end{array}$ & $\begin{array}{c}108^{1} \\
47^{2}\end{array}$ & $\begin{array}{l}92^{1} \\
35^{2}\end{array}$ \\
\hline \multirow{2}{*}{ Equine } & UF & $\begin{array}{c}5000 \\
10000\end{array}$ & $\begin{array}{c}5.4 \\
11.6\end{array}$ & $\begin{array}{l}0.23 \\
0.51\end{array}$ & $\begin{array}{l}0.01 \\
0.09\end{array}$ \\
\hline & Ret. & $\begin{array}{c}5000 \\
10000\end{array}$ & $\begin{array}{c}42.2 \\
53-78\end{array}$ & $\begin{array}{c}24.7 \\
50-76\end{array}$ & $\begin{array}{c}13.0 \\
30-49\end{array}$ \\
\hline
\end{tabular}

${ }^{1}$ First milking; ${ }^{2}$ second milking; n.d. $=$ not determined.

TS: Total Solids; TNM: Total Nitrogen Matter ( $\times$ × 6.38); IgG: Immunoglobulin G.

serocolostrum, use of a $100 \mathrm{~kg} \cdot \mathrm{mol}^{-1} \mathrm{MWCO}$ membrane, carried out in order to remove not only lactose and soluble mineral salts but also low MW whey proteins, allowed us to reach an enriched $\mathrm{IgG}$ retentate with ratios of TNM/TS close to 0.95 and $\mathrm{IgG} /$ TNM varying between 0.56 and 0.80 . Similar purifications were obtained with caprine and equine serocolostrums. On the other hand, the results obtained with caprine $1 \mathrm{st}$ and 2nd milking colostrum, of which the $\mathrm{IgG} / \mathrm{TNM}$ ratios are, respectively, 0.56 and 0.41 , show that the use of the same UF parameters and the same UF equipment allows to obtain a more IgG-enriched UF retentate (Tab. IV) when the starting material has a higher IgG content. The initial relative ratio between the two milkings, which is $0.56 / 0.41=1.366$, is kept in the final resulting freeze-dried UF retentates (Tab. IV).

\subsection{Recovery of IgG, TGF- $\beta$ and IGF-1 in the proposed process}

In order to prepare large quantities of purified IgG for animal experiments, 4 successive complete trials, each with between 
Table IV. Freeze-dried powders' composition $(\mathrm{g} \cdot 100 \mathrm{~g})$.

\begin{tabular}{lccc}
\hline & TS & TNM & IgG \\
\hline Bovine & $96-99$ & $80-93$ & $51-73$ \\
\hline Caprine & & & \\
1st milking & 99 & 97 & 85 \\
2nd milking & 99 & 94 & 58 \\
\hline Equine & 98 & 91 & 55 \\
\hline
\end{tabular}

TS: Total Solids; TNM: Total Nitrogen Matter ( $\mathrm{N} \times$ 6.38); IgG: Immunoglobulin G.

80 and $90 \mathrm{~kg}$ of bovine colostrum obtained by the mixture of the 2nd, 3rd and 4th milking were realised. The amounts and average compositions of the products obtained at each step of the process, from an $80 \mathrm{~kg}$ batch of colostrum, are indicated in Figure 1.

Because the volume of colostrum cream represented about $10 \%$ of the whole colostrum, recovery of $\mathrm{IgG}$ in skimmed colostrum was found to be, as expected, around $90 \%$. This yield can be increased by cancelling cream separation and directly submitting the diluted whole colostrum to MF with an extended diafiltration step. Losses of IgG during the MF step originated by the lost retentate (6.7 to $5.0 \%$ of the volume used) and the dead volume of the MF equipment used were found to be in the range of 20 to $33 \%$. Losses in the UF step only resulted from the dead volume of the equipment and reached about 10 to $15 \%$. Finally, in our experiments, the global recovery of IgG was at the maximum $64 \%$. Such a recovery can be improved when larger quantities of colostrum are used, seeing that losses due to the dead volumes of the MF and UF equipment are fixed, whatever the volume of treated liquid.

The content in TGF- $\beta$ of the diluted skimmed colostrum was $100.7 \mathrm{ng} \cdot \mathrm{mL}^{-1}$ i.e. $1.47 \mu \mathrm{g}$ per $\mathrm{g}$ of $\mathrm{TNM}$ or $3.03 \mu \mathrm{g}$ per $\mathrm{g}$ of IgG. This determination agrees with those of Pakkanen [26]. The content in the UF retentate was $160.0 \mathrm{ng} \cdot \mathrm{mL}^{-1}$ i.e. $1.80 \mu \mathrm{g}$ per $\mathrm{g}$ of TNM or $1.95 \mu \mathrm{g}$ per $\mathrm{g}$ of IgG, that showed a loss in this component during the UF step in the ultrafiltrate in spite of the fact that growth factor should be present in dairy products as a dimer of $2 \times 12720 \mathrm{~g} \cdot \mathrm{mol}^{-1}$ [23].

The content in IGF-1 of the diluted skimmed colostrum was $206 \mathrm{ng} \cdot \mathrm{mL}^{-1}$ i.e. $3 \mu \mathrm{g}$ per $\mathrm{g}$ of TNM or $6.2 \mu \mathrm{g}$ per $\mathrm{g}$ of IgG. The determined content in UF retentate was $200.0 \mathrm{ng} \cdot \mathrm{mL}^{-1}$ i.e. $2.25 \mu \mathrm{g}$ per $\mathrm{g}$ of TNM or $2.44 \mu \mathrm{g}$ per $\mathrm{g}$ of $\mathrm{IgG}$. That also confirmed the high loss in the ultrafiltrate which was determined as $5.3 \mathrm{ng} \cdot \mathrm{mL}^{-1}$ on average, as shown in Figure 1. Such a loss in serocolostrum ultrafiltrate with a $8 \mathrm{~kg} \cdot \mathrm{mol}^{-1}$ UF membrane agrees with the MW of IGF-1 (7 $649 \mathrm{~g} \cdot \mathrm{mol}^{-1}$ according to Rindernecht and Humbel [30] and Frankenne et al. [9]) but does not agree with the results of Vega et al. [38] who claimed that in colostrum, most of the IGF- 1 is bound with a $45 \mathrm{~kg} \cdot \mathrm{mol}^{-1}$ protein.

\subsection{Bacteriological quality of the products}

In agreement with the literature, all the colostrums were highly contaminated with a Total Count higher than $10^{6} \mathrm{CFU} \cdot \mathrm{mL}^{-1}$ and $10^{4} \mathrm{CFU} \cdot \mathrm{mL}^{-1}$ coliforms. No more than 1 to 2 mesophilic CFU. $\mathrm{mL}^{-1}$ were enumerated in the serocolostrums obtained through MF with a $0.1 \mu \mathrm{m}$ pore sized membrane. But, because of the difficulty of satisfactory sanitation of spiral wound UF equipment, UF retentates as their resulting freeze-dried powders have a slightly increased mesophilic TC (around $10^{2} \mathrm{CFU} \cdot \mathrm{mL}^{-1}$ ) but no enumerable coliform.

\section{CONCLUSION}

Treatment at mild temperatures (37$40{ }^{\circ} \mathrm{C}$ ) of whole colostrum by membrane microfiltration using a pore size of $0.1 \mu \mathrm{m}$ and the hydraulic concept of uniform transmembrane pressure (UTP) or an equivalent device allows to obtain a serocolostrum free of blood and somatic cells and with a high bacteriological quality (less than $10 \mathrm{CFU} \cdot \mathrm{mL}^{-1}$ ). The IgG as well as the other minor components contained in this "serocolostrum", which can be obtained with a satisfactory yield if an extended diafiltration 
80 kg Bovine colostrum

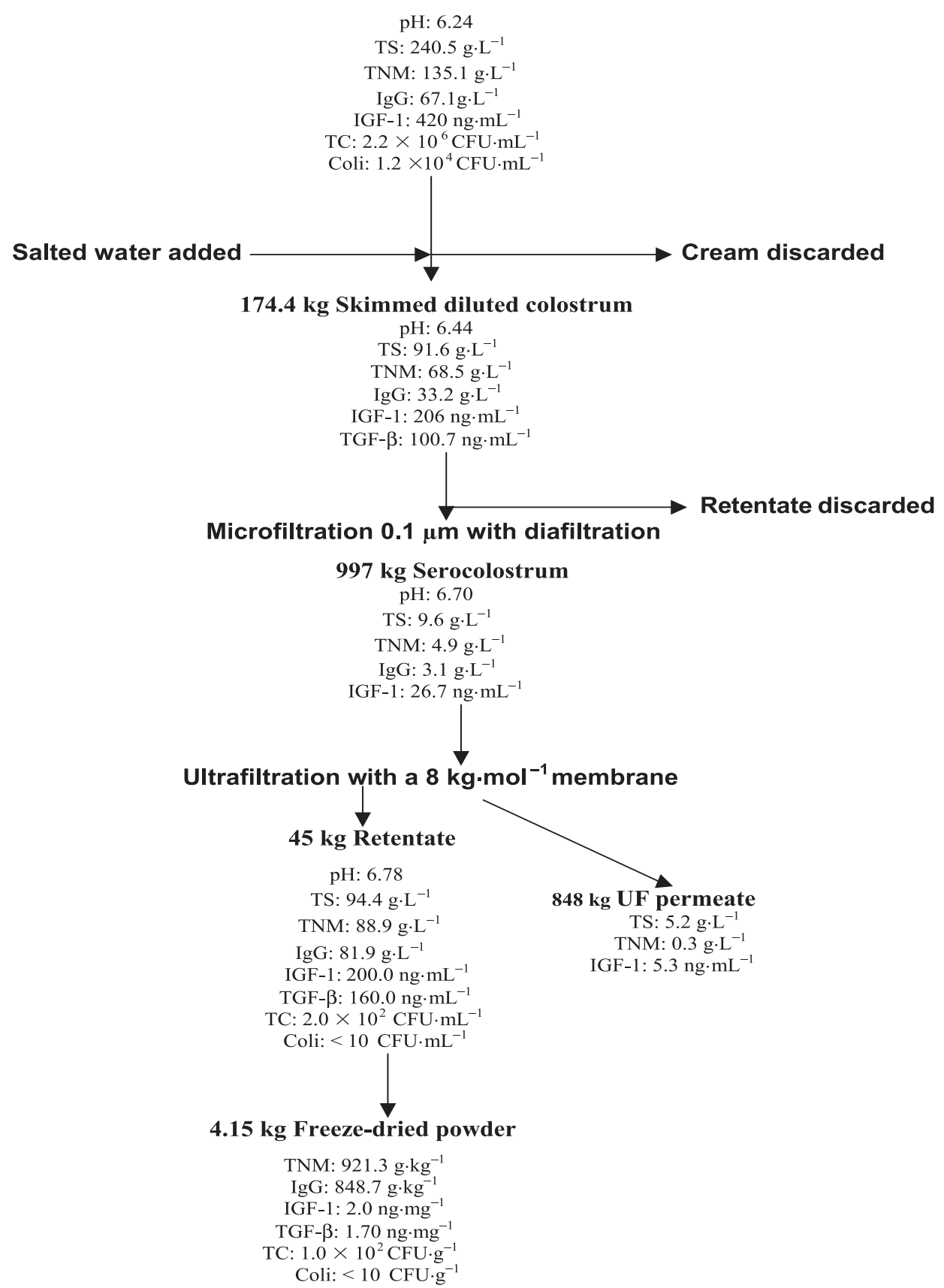

Figure 1. Separation of serocolostrum components by membrane processes. 
step is carried out, can be used directly for feeding young animals or concentrated by membrane UF (membranes with a molecular cut-off of $5 \mathrm{~kg} \cdot \mathrm{mol}^{-1}$ appear to be the most appropriate for a maximum retention of growth factors) in order to obtain purified products. The preliminary animal trials done with the freeze-dried powders of IgG obtained in our study showed that they kept their physiological properties.

Indeed, as mentioned above, the bovine freeze-dried UF retentates obtained from this study were given by le Huërou-Luron et al. [17] and Marion et al. [22] to newly weaned piglets. Compared with the control group, a highly interesting increase in both duodenal villous height of $22 \%$ and protein synthesis of $21 \%$ in the duodenum was seen [22]. The obtained results are in favour of an improved gut health around weaning in piglets [17]

Equine frozen and freeze-dried UF retentates made according to the developed process were used by Chavatte-Palmer et al. [3] and by Clément et al. [4] for the feeding of newborn foals. Absorption of IgG as well as the foals' immunisation measured by the IgG plasma level were found to be identical to those of foals receiving high quality equine colostrum $[3,4]$.

Acknowledgements: The authors are indebted to M. Bourtourault for the determination of growth factors.

\section{REFERENCES}

[1] Alais C., Science du Lait, Ed. SEPAIC, Paris, France, 1984.

[2] Brody E.P., Biological activities of bovine glycomacropeptide, Brit. J. Nutr. 84 (Suppl. 1) (2000) S39-S46.

[3] Chavatte-Palmer P., Duvaux-Ponter C., Arnaud G., Piot M., Maubois J.-L., Grongnet J.-F., Brugère L., Clément F., Absorption of IgG in the foal: efficiency of a freeze dried colostral immunoglobulin product; effect of the $1 \mathrm{st}$ suckling time in: 52nd annual Proceeding of European Federation of Zootechnie, August 26-29th, Budapest, Hungary, 2001.

[4] Clément F., Duvaux-Ponter C., Arnaud G., Piot M., Maubois J.-L., Grongnet J.-F.,
Brugère L., Tournié M., Detrimont L., ChavattePalmer P., Efficiency of IgG absorption in the foal, Theriogenology 58 (2002) 805-808.

[5] Fauquant J., Maubois J.-L., Pierre A., Microfiltration du lait sur membrane, Techn. Lait. 1028 (1988) 21-23.

[6] Foley J.A., Otterby D.E., Availability, storage, treatment, composition and feeding value of surplus colostrum: A review, J. Dairy Sci. 61 (1978) 1033-1060.

[7] Garcin I., Paviot G., Composition cosmétique ou pharmaceutique à usage cutané et procédé pour la préparation d'une telle composition, Brevet européen Gattefossé S.A. $\mathrm{n}^{\circ} 0334776$ (1989).

[8] Grongnet J.F., Dos Santos G.T., Piot M., Toullec R., Influence of some food additives on IgG plasma concentrations in newborn calves fed an immunoglobulin solution extracted from colostrum, Lait 76 (1996) 303-309.

[9] Frankenne F., Marcotty C., Duyckaerts A., Beeumen J., Maghuin-Rogister G., Purification and characterization of insuline-like growth factor-I from cow colostrum, Biochem. Soc. Trans. 17 (1989) 602.

[10] Hagiwara K., Katakoa S., Yamanaka H., Kirisawa R., Iwai H., Detection of cytokines in bovine colostrum, Vet. Immunol. Immunopathol. 76 (2000) 183-190.

[11] Hilpert H., Brussow H., Mietens C., Sidoti J., Lerner L., Werchau H., Use of bovine milk concentrate containing antibody to rotavirus to treat rotavirus gastroenteritis in infants, $\mathrm{J}$. Infec. Dis. 156 (1987) 158-165.

[12] Honorio-Franca A.C., Launay P., CarneiroSampaio M.M., Monteiro R., Colostral neutrophils express Fc alpha receptors (CD 89), lacking gamma chain association and mediate noninflammatory properties of IgA, J. Leukocyte. Biol. 69 (2001) 289-296.

[13] Houdinière A., Le colostrum de vache : composition, propriétés, répercussion en industrie laitière, Lait 241 (1945) 27-50.

[14] Journal Officiel, 06 Septembre 2002. Arrêté du 20 Août 2002 relatif aux denrées et ingrédients alimentaires traités par ionisation, 2002.

[15] Laato M.K., Jalkanen M., Jalonen H., Aalto J., Kanttinen A., Pakkanen, R., Method for the improvement of wound healing and composition therefore, PCT WO Patent 95/00155 (1994).

[16] Larson B.L., Immunoglobulins of the mammary secretions in: Advanced dairy Chemistry: Proteins (Vol. 1), Fox P.F. (Ed.), Elsevier Applied Science, London, UK, 1992, pp. 231-254.

[17] Le Huërou-Luron I., Marion J., Bebin K., Thomas F., Ganier P., Thibault J.N., Le Dividich J., Supplementation of a weaning diet with a 
bovine colostrum extract minimises postweaning duodenal structural, but not functional, alterations in 7-d-old piglets in: Digestive Physiology in Pigs, 9th International. Symposium, Banff, AB, Canada, Vol. 2, (2003) 238-240.

[18] Leszek J., Inglot A.D., Januz M., Lisowski J., Krukowska K., Georgiades J.A., Colostrinin ${ }^{\circledR}$ : a Proline-Rich Polypeptide (PRP) complex isolated from ovine colostrum for treatment of Alzeimer's disease. A double blind, placebo controlled study, Archivum Immunol. Ther. Exp. 47 (1999) 377-385.

[19] Louveau I., Bonneau M., Salter D.N., Agerelated changes in plasma porcine growth hormone $(\mathrm{GH})$ profiles and insulin-like growth factor (IGF-1) concentrations in Large White and Meishan pigs, Reprod. Nutr. Dev. 31 (1991) 205-216.

[20] Mancini G., Carbonara A.O., Heremans J.H., Immunological quantification of antigens by single radioimmunochemical quantitation, Immunochemistry 2 (1965) 235-259.

[21] McFadden T.B., Besser T.E., Barrington G.M., Regulation of immunoglobulin transfer into mammary secretions of ruminants, in: Milk composition, production and biotechnology, Welch R.A.S., Burns D.J.W., Davis S.R., Popay A.I., Prosser C.J. (Eds.), C.A.B. international, Oxon, UK, 1997, pp. 133-152.

[22] Marion J., Bebin K., Le Huërou-Luron I., Piot M., Louveau I., Ganier P., Thibault J.N., Maubois J.-L., Sève B., Le Dividich J., La supplémentation de l'aliment de sevrage en un extrait de colostrum bovin augmente la hauteur des villosités dans le duodénum du porcelet sevré, Journées de la Recherche Porcine, Paris France 34 (2002) 103-108.

[23] Marquardt H., Lioubin M.N., Ikeda T., Complete amino acid sequence of transforming growth factor, type $\beta_{2}$, J. Biol. Chem. 262 (1987) 12127-12131.

[24] Maubois J.-L., Fauquant J., Famelart M.-H., Caussin F., Milk microfiltrate, a convenient starting material for fractionation of whey proteins and derivatives in: 3rd International Symposium of Whey Conference, September 11-14, Behr's Verlag (Ed.), Munich Germany (2001) pp. 59-72.

[25] Mortensen U., A process for the preparation of colostrum, PCT WO n 99/55168 (1999).

[26] Pakkanen R., Determination of transforming growth factor $\beta_{2}$, J. Immunoassay 19 (1998) 23-37.

[27] Pakkanen R., Aalto J., Growth factors and antimicrobial factors in bovine colostrum, Int. Dairy J. 7 (1997) 285-297.
[28] Playford R.J., Mc Donald C.E., Johnson W.S., Colostrum and milk derived peptides growth factors for the treatment of gastrointestinal disorders, Amer. J. Clin. Nutr. 72 (2000) 5-14.

[29] Plettenberg A., Stoehr A., Stellbrink H., Albrecht H., Meigel W., A preparation from bovine colostrum in the treatment of HIVpositive patients with chronic diarrhoea, Clin. Investigator 71 (1993) 42-45.

[30] Rindernecht E., Humbel R.E., The amino acid sequence of human insulin growth factor I and its structural homology with proinsulin, J. Biol. Chem. (1976) 2769-2776.

[31] Rump J.A., Arndt R., Arnold A., Bendick C., Dichtelmuller H., Franke M., Helm E., Jager J., Kampmann B., Kolb P., Kreuz W., Lissner R., Meigel W., Ostendorf P.L., Peter H., Plettenberg A., Schedel I., Stellbrink H., Stephan W., Treatment of diarrhoea in human immunodeficiency virus-infected patients with immunoglobulins from bovine colostrum, Clin. Investigator 70 (1992) 588-594.

[32] Saboya L., Maubois J.-L., Current developments of microfiltration technology in the dairy industry, Lait 80 (2000) 541-543.

[33] Saboya L., Goudédranche H., Maubois J.-L., Lerayer A.L.S., Lortal S., Impact of broken cells of lactococci and propionibacteria on the ripening of Saint-Paulin UF-cheeses: extent of proteolysis and GC-MS profiles, Lait 81 (2001) 699-713.

[34] Sandblom R.M., Filtering process, Swedish patent $n^{\circ} 7416257$ (1974).

[35] Scammell A.W., Production and uses of colostrum, Aust. J. Dairy Technol. 56 (2001) 74-82.

[36] Schroten H., Kuczera F., Kohler H., Adam R., Opsonophagocytosis versus lectiophagocytosis in human milk macrophages, Adv. Exp. Med. Biol. 478 (2000) 95-107.

[37] Schuck P., Piot M., Méjean S., Le Graët Y., Brulé G., Maubois J.-L., Déshydratation par atomisation de phosphocaséinate natif obtenu par microfiltration sur membrane, Lait 74 (1994) 375-388.

[38] Vega J.R., Gibson C.A., Skaar T.C., Hadsell D.L., Baumrucker C.R., Insulin-like growth factor (IGF)-I and II and IGF binding protein in serum and mammary secretions during the dry period and early lactation in dairy cows, J. Anim. Sci. 69 (1991) 2538-2547.

[39] Whyte P.B.D., Colostrum, preparation, Australian Patent $\mathrm{n}^{\circ} 644468$ (1991).

[40] Whyte P.B.D., Colostrum, preparation and storage, Australian Patent n ${ }^{\circ} 668033$ (1994). 